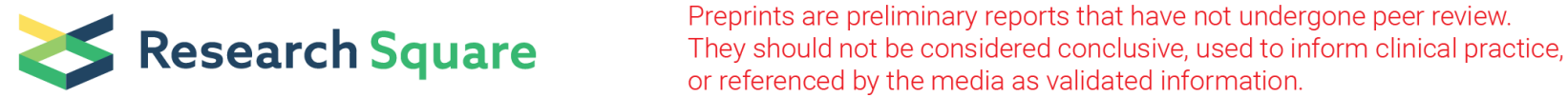

\section{Tibial Cortex Transverse Distraction Followed by Open Correction with Internal Fixation: Two-stage Management for Foot and Ankle Deformity with Ulcers}

\author{
Yaxing Li \\ Sichuan University West China Hospital \\ Xi Liu \\ Sichuan University West China Hospital \\ Yu Chen \\ Sichuan University West China Hospital \\ Jie Tan \\ Sichuan University West China Hospital \\ Jun Chen \\ Sichuan University West China Hospital \\ Huiqi Xie \\ Sichuan University West China Hospital \\ Zhang Hui ( $\sim$ caesarzh@163.com )
}

Sichuan University West China Hospital https://orcid.org/0000-0002-8498-1947

\section{Research article}

Keywords: deformity, ulcer, tibial cortex transverse distraction, correction, llizarov

Posted Date: October 9th, 2020

DOl: https://doi.org/10.21203/rs.3.rs-88622/v1

License: (c) (i) This work is licensed under a Creative Commons Attribution 4.0 International License. Read Full License 


\section{Abstract}

Aim Foot and ankle deformities with concurrent ulcers remain challenging. Conventional treatments are often timeconsuming and difficult. This study aims at assessing the feasibility and results of tibial cortex transverse distraction (TCTD) followed by open correction with internal fixation (OCIF) for foot and ankle deformity with concurrent ulcers.

Methods A retrospective analysis was conducted. Between 2010 and 2019, a two-stage management of TCTD followed by OCIF was performed in 13 patients (13 feet). The clinical data of all patients was recorded and analyzed.

Results The TCTD and wound debridement were performed in all patients, and an additional Ilizarov correction technique was added in two patients. All ulcers were healed in 3 months after first-stage treatment. The average external fixation time was 135.5 (median, 138.0; range, 49-173) days. After second-stage operative correction, the patients were followed-up for an average of 28.0 (range, 24-33) months. At the final follow-up, the average Dimeglio score of deformity was decreased from 6.7 (range, 3-9) to 0.5 (median, 1; range, 0-1), and the average AOFAS score was improved from 42.9 (range, 14-80) to 82.6 (range, 70-97). Complications include one case of mild displacement of the osteotomized cortex and one case of pin-tract infection. No relapse of ulcers or deformity was observed.

Conclusion The two-stage management of TCTD followed by OCIF could be considered as an alternative treatment for foot and ankle deformities combined with chronic ulcers.

Level of Evidence Level IV, retrospective case series.

\section{Introduction}

Foot and ankle deformities caused by various diseases can result in abnormal foot pressure distribution [1]. This longterm high pressure in some areas of foot predisposes callosities, soft-tissue damage, and even chronic ulcers [2-4]. The management of foot and ankle deformity with concurrent ulcers is challenging.

Unfortunately, as far as we know, only one study has focused on the management of this complex condition [4]. In their study, Kliushin et al applied an Ilizarov corrective frame for management of neurologic deformity of ankle and foot with concurrent osteomyelitis in a total of 77 patients [4]. Ulcer healing and eradication of infection could be simultaneously obtained during the process of deformity correction using an llizarov fixator. However, the lengthy duration of external fixation caused serious inconvenience to the patients and limited their quality of life.

The application of open correction with internal fixation (OCIF) could avoid prolonged external fixation but is restricted by the existence of infected ulcers. When OCIF is selected, the management of infected ulcers is an important and priority step in achieving an ulcer-free plantigrade foot in these patients. Conventional treatments for chronic ulcers include debridement, infection control, mechanical off-loading, and wound care therapies [5, 6]. For some patients, however, the long process of treatment makes it difficult to adhere the treatment, or the chronic ulcers still fail to heal despite treatment, requiring advanced methods are for adequate wound healing $[7,8]$. Tibial cortex transverse distraction (TCTD), a novel technique based on the "tension-stress principle" proposed by llizarov $[9,10]$, has been shown as an effective treatment for chronic ulcers resulting from diabetes mellitus, thromboangiitis obliterans, and chronic ischemic diseases [11-13]. To our best knowledge, however, the application of tibial cortex transverse distraction in foot and ankle deformity with concurrent ulcers has not been previously reported.

Consequently, we hypothesized that (1) first-stage treatment using tibial cortex transverse distraction technique would be an effective method to facilitate healing of chronic pressure ulcers caused by foot and ankle deformities, and (2) second-stage treatment of OCIF could provide effective correction for foot and ankle deformities with less recurrence 
risk of infection and deformity. To prove these hypotheses, a retrospective study was performed to evaluate the outcomes of the two-stage treatment, TCTD followed by OCIF, in a consecutive series of 13 patients (Fig. 1).

\section{Patients And Material}

A retrospective review of collected data between 2010 and 2019 from our department database was conducted under the ethical approval by the Research Ethics Committee of West China Hospital. We identified 25 patients (27 feet) who underwent the treatment for foot and ankle deformity with concurrent ulcers (Fig. 2A to 2F). The inclusion criteria of this study include patients who were suffering from foot and ankle deformity with non-healing or recurrent ulcers, who had not responded to previous treatments, and who underwent TCTD followed by OCIF. Previous treatments include non-operation management, debridement, skin grafting and flap transplantation. The exclusion criteria include Charcot arthropathy, peripheral vascular dysfunction, diabetes mellitus, or follow-up of $<24$ months. Based on the inclusion and exclusion criteria, the final analysis included 13 patients (13 feet). The details of the patients are shown in Table 1.

Table I. Descriptive characteristics of patients

\begin{tabular}{|c|c|c|c|c|c|c|c|c|c|}
\hline Case & $\begin{array}{c}\text { Age } \\
\text { (years) }\end{array}$ & Gender & Side & Etiology & $\begin{array}{l}\text { Duration of } \\
\text { deformity } \\
\text { (years) }\end{array}$ & $\begin{array}{c}\text { Type of } \\
\text { deformity }\end{array}$ & $\begin{array}{l}\text { Duration of } \\
\text { ulcer } \\
\text { (years) }\end{array}$ & $\begin{array}{l}\text { Site of } \\
\text { ulcer }\end{array}$ & $\begin{array}{l}\text { Size } \\
\text { of } \\
\text { ulcer } \\
\left(\mathrm{cm}^{2}\right)\end{array}$ \\
\hline 1 & 54 & female & right & $\begin{array}{c}\text { Congenital } \\
\text { neurological } \\
\text { diseases }\end{array}$ & 50 & Equinocavovarus & 4 & forefoot & 6.8 \\
\hline 2 & 46 & female & right & $\begin{array}{l}\text { Charcot-Marie- } \\
\text { Tooth Disease }\end{array}$ & 30 & Equinocavovarus & 6 & forefoot & 9.0 \\
\hline 3 & 41 & female & right & Poliomyelitis & 37 & Equinocavovarus & 2 & forefoot & 3.6 \\
\hline 4 & 38 & male & right & Trauma sequelae & 2 & Equinocavovarus & 1 & forefoot & 0.8 \\
\hline 5 & 25 & female & right & Myelomeningocele & 13 & Equinocavovarus & 1 & hindfoot & 100.0 \\
\hline 6 & 18 & male & left & $\begin{array}{l}\text { Congenital } \\
\text { neurological } \\
\text { diseases }\end{array}$ & 18 & Equinocavovarus & 3 & midfoot & 6.2 \\
\hline 7 & 16 & female & right & $\begin{array}{c}\text { Congenital } \\
\text { neurological } \\
\text { diseases }\end{array}$ & 16 & Equinovarus & 1 & forefoot & 9.0 \\
\hline 8 & 30 & male & right & Myelomeningocele & 20 & Equinocavovarus & 4 & forefoot & 0.8 \\
\hline 9 & 48 & female & right & $\begin{array}{c}\text { Congenital } \\
\text { neurological } \\
\text { diseases }\end{array}$ & 48 & Equinocavovarus & 2 & midfoot & 1.0 \\
\hline 10 & 30 & female & left & $\begin{array}{l}\text { Congenital } \\
\text { neurological } \\
\text { diseases }\end{array}$ & 30 & Equinovarus & 2 & midfoot & 0.8 \\
\hline 11 & 14 & male & right & $\begin{array}{c}\text { Congenital } \\
\text { neurological } \\
\text { diseases }\end{array}$ & 14 & Equinocavovarus & 2 & midfoot & 2.6 \\
\hline 12 & 23 & female & right & Myelomeningocele & 14 & Equinocavovarus & 1 & forefoot & 4.0 \\
\hline 13 & 57 & male & left & $\begin{array}{c}\text { Congenital } \\
\text { neurological } \\
\text { diseases }\end{array}$ & 50 & Equinocavovarus & 2 & midfoot & 1.0 \\
\hline
\end{tabular}

\section{Management}

\section{First stage}

Preoperatively, plain radiography, computed tomography (CT) scans, magnetic resonance imaging (MRI), color Doppler sonography (CDS) of peripheral blood vessels, routine blood examination, erythrocyte sedimentation rate (ESR) and serum level of C-reactive protein (CRP), and bacterial culture of wound were performed to determine a 
reasonable operation plan. Empirical antibiotics were administered as early as possible. All procedures were performed under general anesthesia in the supine position by a senior surgeon.

Proximal tibial corticotomy was firstly performed with the infected ulcers covered by sterile dressing. An $8 \mathrm{~cm}$ longitudinal incision was made on the anteromedial of lower leg to expose the tibial. The tibial periosteum was exposed but not removed from the cortex. After the rough location of corticotomy on the medial cortex of tibia was determined, a cortical window with a size of $1.5 \mathrm{~cm} \cdot 10 \mathrm{~cm}$ was osteotomized by carefully drilling multiple holes in ipsilateral cortex with the help of a special guide. During this process, cool normal saline was used to prevent thermal injury and all surrounding tissues including the periosteum should be protected as much as possible. After drilling, two distraction pins were inserted through unilateral cortex for postoperative distraction of osteotomized cortex. Then, an osteotome was used to connect all the holes so as to separate the cortex from the tibial shaft. The next step was to install a special llizarov frame which consist of (1) two tibial rings (attached with 1 wire and 1 half pin on each ring or 2 half pins on each ring) for fixation and (2) a straight part for transverse distraction (Fig. 2G to 2l). For patients with severe deformity, limited soft-tissue releases were performed to address tissue contracture and an additional llizarov frame was simultaneously installed at this time to gradually correct soft tissue. The operative incisions were irrigated before closing. Sterile gauze was used to cover and dress the wound, which would prevent contamination of the corticotomy wound by debridement. Then, thorough debridement was performed at the site of ulcers to remove all unhealthy, infected, and devitalized tissue. Different samples of tissues were collected and sent for bacterial culture and histopathologic examination.

Postoperatively, patients were treated with sensitive antibiotic and antithrombotic prophylaxis. Sensitive antibiotics were selected according to the result of bacterial culture. After latency period of 5 days, transverse distraction was performed at a rate of $0.25 \mathrm{~mm}$ every 6 hours. Outward distraction was applied for 21 days, then inward distraction was applied for another 21 days to reposition the osteotomized cortex to its original position. The process of distraction was monitored by regular plain radiography. The distraction frame was usually removed 12 weeks after total distraction when bone healing was obtained. In patients with severe deformity, the process of gradual correction was simultaneously conducted with the process of transverse distraction. In other words, the two processes were independently performed and did not disrupt each other. The corrective frame was removed when rough correction was achieved. Patients were discharged 7 days after surgery when they learned to manage the llizarov frame. Mechanical unloading was maintained at the site of ulcers. Routine wound care was performed in an outpatient clinic, and no more additional technique was applied.

\section{Second stage}

After the ulcers healing with three consecutive normal results ESR and CRP, patients were readmitted for second-stage corrective surgery. Weightbearing plain radiography, full-length lower extremity radiographs, CT scans, and electromyogram (EMG) of lower limbs were performed before operation. An individualized open surgery was performed to correct the corresponding deformities (Fig. 2J to 20). The procedures of each patient are shown in Table 2.

Table II. Outcomes of patients 


\begin{tabular}{|c|c|c|c|c|c|c|c|c|c|c|}
\hline Case & $\begin{array}{l}\text { Follow- } \\
\text { up }_{\text {(months) }}\end{array}$ & $\begin{array}{l}\text { Pre-op } \\
\text { deformity }\end{array}$ & $\begin{array}{l}\text { Pre-op } \\
\text { AOFAS }\end{array}$ & $\begin{array}{l}\text { First- } \\
\text { stage } \\
\text { treatment }\end{array}$ & $\begin{array}{c}\text { EFT } \\
\text { (days) }\end{array}$ & $\begin{array}{c}\text { Ulcers } \\
\text { healing } \\
<3 \\
\text { months }\end{array}$ & $\begin{array}{l}\text { Second-stage } \\
\text { treatment }\end{array}$ & $\begin{array}{l}\text { Post-op } \\
\text { deformity }\end{array}$ & $\begin{array}{l}\text { Post- } \\
\text { op } \\
\text { AOFAS }\end{array}$ & Complications \\
\hline 1 & 27 & 9 & 34 & $\begin{array}{l}\text { TCTD, } \\
\text { WD }\end{array}$ & 142 & Yes & $\begin{array}{c}\text { Midfoot } \\
\text { osteotomy, } \\
\text { proximal 1st } \\
\text { metatarsal } \\
\text { osteotomy, } \\
\text { interphalangeal } \\
\text { fusion }\end{array}$ & 0 & 70 & None \\
\hline 2 & 27 & 7 & 26 & $\begin{array}{l}\text { TCTD, } \\
\text { WD }\end{array}$ & 49 & Yes & $\begin{array}{c}\text { Proximal } 1^{\text {st }} \\
\text { metatarsal } \\
\text { osteotomy, } \\
\text { calcaneal }\end{array}$ & 1 & 72 & $\begin{array}{c}\text { Mild } \\
\text { displacement } \\
\text { of the } \\
\text { osteotomized } \\
\text { cortex }\end{array}$ \\
\hline 3 & 25 & 6 & 65 & $\begin{array}{l}\text { TCTD, } \\
\text { WD }\end{array}$ & 139 & Yes & $\begin{array}{l}\text { Midfoot } \\
\text { osteotomy, } \\
\text { limb }\end{array}$ & 0 & 97 & $\begin{array}{l}\text { Pin-tract } \\
\text { infection }\end{array}$ \\
\hline 4 & 24 & 4 & 54 & $\begin{array}{l}\text { TCTD, } \\
\text { WD }\end{array}$ & 136 & Yes & $\begin{array}{l}\text { lengthening } \\
\text { Midfoot } \\
\text { osteotomy, } 1^{\text {st }} \\
\text { MTP fusion, } 2^{\text {nd }} \\
\text { and } 3^{\text {rd }} \text { MTP } \\
\text { resection } \\
\text { arthroplasty }\end{array}$ & 0 & 89 & None \\
\hline 5 & 31 & 9 & 30 & $\begin{array}{l}\text { TCTD, } \\
\text { WD ICT }\end{array}$ & 165 & Yes & Ankle fusion & 1 & 80 & None \\
\hline 6 & 26 & 9 & 52 & $\begin{array}{l}\text { TCTD, } \\
\text { WD }\end{array}$ & 138 & Yes & $\begin{array}{l}\text { Midfoot } \\
\text { osteotomy, } \\
\text { calcaneal } \\
\text { osteotomy }\end{array}$ & 1 & 90 & None \\
\hline 7 & 31 & 5 & 37 & $\begin{array}{l}\text { TCTD, } \\
\text { WD }\end{array}$ & 130 & Yes & Ankle fusion, & 0 & 78 & None \\
\hline 8 & 25 & 3 & 58 & $\begin{array}{l}\text { TCTD, } \\
\text { WD }\end{array}$ & 141 & Yes & $\begin{array}{l}\text { lengthening } \\
\text { 1st-5th } \\
\text { metatarsal }\end{array}$ & 0 & 87 & None \\
\hline 9 & 31 & 7 & 14 & $\begin{array}{l}\text { TCTD, } \\
\text { WD }\end{array}$ & 136 & Yes & $\begin{array}{l}\text { Subtalar } \\
\text { arthrodesis, } \\
\text { calcaneocuboid } \\
\text { arthrodesis, } \\
\text { talonavicular } \\
\text { arthrodesis }\end{array}$ & 0 & 78 & None \\
\hline 10 & 33 & 7 & 34 & $\begin{array}{l}\text { TCTD, } \\
\text { WD }\end{array}$ & 138 & Yes & $\begin{array}{l}\text { Subtalar } \\
\text { arthrodesis, } \\
\text { calcaneocuboid } \\
\text { arthrodesis, } \\
\text { talonavicular } \\
\text { arthrodesis }\end{array}$ & 1 & 84 & None \\
\hline 11 & 29 & 9 & 53 & $\begin{array}{l}\text { TCTD, } \\
\text { WD, ICT }\end{array}$ & 173 & Yes & $\begin{array}{l}\text { Midfoot } \\
\text { osteotomy }\end{array}$ & 1 & 80 & None \\
\hline 12 & 29 & 4 & 80 & $\begin{array}{l}\text { TCTD, } \\
\text { WD }\end{array}$ & 133 & Yes & $\begin{array}{l}\text { Proximal } 1^{\text {st }} \\
\text { and } 5^{\text {th }} \\
\text { metatarsal } \\
\text { osteotomy, } \\
\text { calcaneal }\end{array}$ & 1 & 90 & None \\
\hline 13 & 26 & 8 & 21 & $\begin{array}{l}\text { TCTD, } \\
\text { WD }\end{array}$ & 141 & Yes & $\begin{array}{l}\text { Subtalar } \\
\text { arthrodesis, } \\
\text { calcaneocuboid } \\
\text { arthrodesis, } \\
\text { talonavicular } \\
\text { arthrodesis, } \\
\text { Proximal 1st } \\
\text { metatarsal } \\
\text { osteotomy } \\
\end{array}$ & 1 & 79 & None \\
\hline
\end{tabular}

Pre-op, preoperative; EFT, external fixation time; Post-op, postoperative; TCTD, tibial cortex transverse distraction; WD, wound debridement; ICT, Ilizarov correction technique; MTP, metatarsophalangeal.

Postoperatively, the foot and ankle were immobilized in a night splint. Patient-specific exercises was performed under professional supervision. Full weightbearing was usually allowed when signs of bone healing present on the plain 
radiography. Routine follow-up examinations were performed 1, 3, 6, 12 months postoperatively.

\section{Assessments}

Rating system reported by Dimeglio et al [14] was used to assess the score of pre- and postoperative deformity. The American Orthopaedic Foot and Ankle Society (AOFAS) ankle-hindfoot score [15] was administered to assess the functional status. Postoperative AOFAS scores were categorized as excellent (90-100), good (80-89), fair (65-79), and poor (less than 65). Three levels of patient satisfaction including very satisfied, satisfied, and dissatisfied were applied. All perioperative complications recorded.

\section{Statistical analysis}

SPSS statistical software package version 24.0 (IBM Inc., New York, USA) was used for statistical analysis. Kolmogorov-Smirnov test was used to test the normality of data. All data was presented as average with standard deviation and median with interquartile range. The Student's t-test was used to compare the normally distributed data. The Wilcoxon's signed-rank test was conducted to compare the non-normally distributed data. Statistical significance was set at $\mathrm{p}<0.05$.

\section{Result}

There were 5 males and 8 females with an average age of 33.8 (range, 14-57) years. Ten patients had a right-side lesion, and three patients had a left-side lesion. The etiology of deformity included seven cases of congenital neurological disease, one case of Charcot-Marie-Tooth disease, one case of trauma sequelae, and three cases of myelomeningocele. The average duration of deformity was 26.3 (range, 2-50) years. The types of deformity included equinocavovarus in eleven patients and equinovarus in two patients. The average duration of ulcers was 2.4 (median, 2 ; range, 1-6) years. The ulcers were located at forefoot in seven patients, at midfoot in five patients, and at hindfoot in one patient. The average size of ulcers was 11.2 (median, 3.6; range, $0.8-100.0$ ) $\mathrm{cm}^{2}$. The tibial transverse distraction technique and wound debridement were performed in all patients, and an additional llizarov correction technique was added in two patients (Fig. 3). All ulcers were healed in 3 months after first-stage treatment. As the healing process occurred at home, the exact time of ulcers healing was not clear. The average external fixation time was 135.5 (median, 138.0; range, 49-173) days. After second-stage operative correction, the patients were followedup for an average of 28.0 (range, 24-33) months. As shown in Fig. 4, the average Dimeglio score of deformity was decreased from 6.7 (range, 3-9) to 0.5 (median, 1; range, 0-1), and the average AOFAS score was improved from 42.9 (range, 14-80) to 82.6 (range, 70-97) at the final follow-up. The mild displacement of the osteotomized cortex was observed in one patient who removed her external frame too early. One patient experienced pin-tract infection without loosening, and she was successfully treated with pin-tract care and oral antibiotics. Among all patients, no relapse of ulcers or deformity was observed during the follow-up period. The results of patients are shown in Table 2.

\section{Discussion}

The treatment objectives of foot and ankle deformities combined with chronic ulcers are infection eradication, ulcers healing, and obtaining a plantigrade and functional foot. In the present study, we adopted a two-stage therapeutic strategy that includes the first-stage treatment focusing on infection eradication and ulcer healing and the secondstage treatment aiming to correct deformity and prevent relapse of ulcers or deformity.

In order to enhance ulcer healing, we employed TCTD as a primary method in the first-stage treatment. As we know, Ilizarov technique is revolutionizing the therapy of deformity correction, bone reconstruction, infection control, and vascular regeneration. Originated from the principle of llizarov, TCTD is a novel technique for treatment of foot ulcers 
$[11,16]$. In a recent study, Chen and colleagues successfully employed optimized proximal TCTD to treat severe and recalcitrant diabetic foot ulcers in 136 patients, and achieved ulcers healing in $96 \%$ of the patients [11]. Based on the outstanding works in previous studies, we proposed that TCTD could also promote the complete healing of chronic ulcers caused by long-term foot and ankle deformity. The TCTD in the first-stage treatment is likely to make it possible to maximize the treatment efficacy of recalcitrant ulcers and minimize the risk of infection and/or relapse. In the second-stage treatment, when the ulcers healed, open operation with internal fixation was allowed to correct various deformities as optimal as possible. Moreover, it was possible to provide the patients with the convenience during the treatment period because there was no need of long-term external fixation. Compare with the results of Kliushin et al, the duration of external fixation (mean, 135.5 days; median, 138.0 days; range, 49-173 days) in the present study was significantly shorter. At the final follow-up, complete healing of ulcers and excellent correction of deformity were achieved in all patients without severe complications. Our results also confirmed that tibial cortex transverse distraction could successfully treat the chronic ulcers in patients with non-diabetes and non-ischemic diseases. This finding is expected to provide some empirical support for expanding the indications of the tibial cortex transverse distraction.

Despite the findings, our study is not without its limitations. Firstly, as a retrospective study with relatively small number of patients, the potential selection bias and confounding bias was inevitable. Secondly, due to lack of a control group, we could not compare our two-stage management with the single-stage management applied by Kliushin et al [4]. As the problem of infected ulcers could be simultaneously solved during the gradual correction by an llizarov method, further works are needed to investigate whether TCTD has more advantages in promoting ulcer healing in patients with recalcitrant ulcers caused by foot and ankle deformities. Thirdly, the operative trauma caused by tibial corticotomy and the tedious process of transverse distraction cannot be neglectable. Regrettably, in this study, we did not apply the improved technique as reported by Chen et al [11], which minimized the size of corticotomy window and shortened the time of distraction and fixation. The smaller corticotomy of $1.5 \mathrm{~cm} \cdot 5.0 \mathrm{~cm}$ and the shorter external fixation of 60 days might show comparable effectiveness and better advantages [11]. Fourthly, we did not record the exact time of ulcers healing, as it occurred at home. Since all ulcers had completely healed at 3 months after first-stage treatment, we thought that ulcers healing time was less than 3 months in all patients. Moreover, considering the medical cost of the patients, we also did not perform CT angiography image or CDS after distraction to assess the change of peripheral blood vessels. However, the results of previous studies have established a role for tibial cortex transverse distraction technique in improving blood flow of lower limb [11-13]. The angiogenesis induced by TCTD was also confirmed in animal experiments [17]. Therefore, we believed that the results of our study confirmed the effectiveness of TCTD as an alternative method for the treatment of chronic ulcers resulted from foot and ankle deformities.

\section{Conclusion}

Our results demonstrated that the two-stage management, including the first-stage treatment based on TCTD and the second-stage treatment of OCIF, could be considered as an effective and safe therapeutic strategy for foot and ankle deformities combined with chronic ulcers. However, prospective controlled studies with large sample sizes are needed to provide further evidence.

\section{Abbreviations}

TCTD: tibial cortex transverse distraction; OCIF: open correction with internal fixation; CT: computed tomography; MRI: magnetic resonance imaging; CDS: color Doppler sonography; ESR: erythrocyte sedimentation rate; CRP: C-reactive protein; EGM: electromyogram; AOFAS: The American Orthopaedic Foot and Ankle Society

Page $7 / 13$ 


\section{Declarations}

\section{Acknowledgements}

We are most grateful to Mrs. Li Zhang for her language editing.

\section{Authors' contributions}

Setting up the research was done by ZH. Manuscript preparation and statistical analysis were done by LYX. Clinical assessment was performed by LX and CY. Radiological assessment and data collection were performed by TJ and CJ. Supervising was done by $\mathrm{ZH}$ and $\mathrm{XHQ}$. All authors read and approved the final manuscript.

\section{Funding}

This research did not receive any specific grant from funding agencies in the public, commercial, or not-for-profit sectors.

\section{Availability of data and materials}

All data generated or analyzed during this study are included in this published article and its supplementary information files.

\section{Ethics approval}

This study was approved by the Ethics Committee of West China Hospital of Sichuan University

\section{Consent for publication}

Not applicable.

\section{Competing interests}

The authors declare that they have no competing interests.

\section{References}

1. Xu C, Wei J, Yan YB, Shang L, Yang XJ, Huang LY, et al. Pedobarographic Analysis following Ponseti Treatment for Unilateral Neglected Congenital Clubfoot. Sci Rep 2018;8(1): p.6270.

2. Barreto JG, Salgado CG. Clinic-epidemiological evaluation of ulcers in patients with leprosy sequelae and the effect of low level laser therapy on wound healing: a randomized clinical trial. BMC Infect Dis 2010;10: p.237.

3. Capobianco CM, Ramanujam CL, Zgonis T. Charcot foot reconstruction with combined internal and external fixation: case report. J Orthop Surg Res 2010;5: p.7.

4. Kliushin NM, Sudnitsyn AS, Subramanyam KN, George J. Management of Neurologic Deformity of the Ankle and Foot With Concurrent Osteomyelitis With the Ilizarov Method. Foot Ankle Int 2018;39(2): p.226-35.

5. Barnes LA, Marshall CD, Leavitt T, Hu MS, Moore AL, Gonzalez JG, et al. Mechanical Forces in Cutaneous Wound Healing: Emerging Therapies to Minimize Scar Formation. Adv Wound Care (New Rochelle) 2018;7(2): p.47-56.

6. Saif AB, Jabbar S, Akhtar MS, Mushtaq A, Tariq M. Effects of topical Vancomycin Dressing on MethicillinResistant Staphylococcus Aureus (MRSA) positive diabetic foot ulcers. Pak J Med Sci 2019;35(4): p.1099-103. 
7. Bus SA, van Deursen RW, Armstrong DG, Lewis JE, Caravaggi CF, Cavanagh PR, et al. Footwear and offloading interventions to prevent and heal foot ulcers and reduce plantar pressure in patients with diabetes: a systematic review. Diabetes Metab Res Rev 2016;32 Suppl 1: p.99-118.

8. Crews RT, Candela J. Decreasing an Offloading Device's Size and Offsetting Its Imposed Limb-Length Discrepancy Lead to Improved Comfort and Gait. Diabetes Care 2018;41(7): p.1400-05.

9. Ilizarov GA. The tension-stress effect on the genesis and growth of tissues. Part I. The influence of stability of fixation and soft-tissue preservation. Clin Orthop Relat Res 1989(238): p.249-81.

10. Ilizarov GA. The tension-stress effect on the genesis and growth of tissues: Part II. The influence of the rate and frequency of distraction. Clin Orthop Relat Res 1989(239): p.263-85.

11. Chen Y, Kuang X, Zhou J, Zhen P, Zeng Z, Lin Z, et al. Proximal Tibial Cortex Transverse Distraction Facilitating Healing and Limb Salvage in Severe and Recalcitrant Diabetic Foot Ulcers. Clin Orthop Relat Res 2020;478(4): p.836-51.

12. Zuo Q, Gao F, Song H, Zhou J. Application of Ilizarov transverse tibial bone transport and microcirculation reconstruction in the treatment of chronic ischemic diseases in lower limbs. Exp Ther Med 2018;16(2): p.1355-59.

13. Kulkarni S, Kulkarni G, Shyam AK, Kulkarni M, Kulkarni R, Kulkarni V. Management of thromboangiitis obliterans using distraction osteogenesis: A retrospective study. Indian J Orthop 2011;45(5): p.459-64.

14. Dimeglio A, Bensahel H, Souchet P, Mazeau P, Bonnet F. Classification of clubfoot. J Pediatr Orthop B 1995;4(2): p.129-36.

15. Kitaoka HB, Alexander IJ, Adelaar RS, Nunley JA, Myerson MS, Sanders M. Clinical rating systems for the anklehindfoot, midfoot, hallux, and lesser toes. Foot \& ankle international 1994;15(7): p.349-53.

16. Baumhauer JF. CORR Insights(R): Proximal Tibial Cortex Transverse Distraction Facilitating Healing and Limb Salvage in Severe and Recalcitrant Diabetic Foot Ulcers. Clin Orthop Relat Res 2020;478(4): p.852-53.

17. Matsuyama J, Ohnishi I, Kageyama T, Oshida H, Suwabe T, Nakamura K. Osteogenesis and angiogenesis in regenerating bone during transverse distraction: quantitative evaluation using a canine model. Clin Orthop Relat Res 2005(433): p.243-50.

\section{Figures}



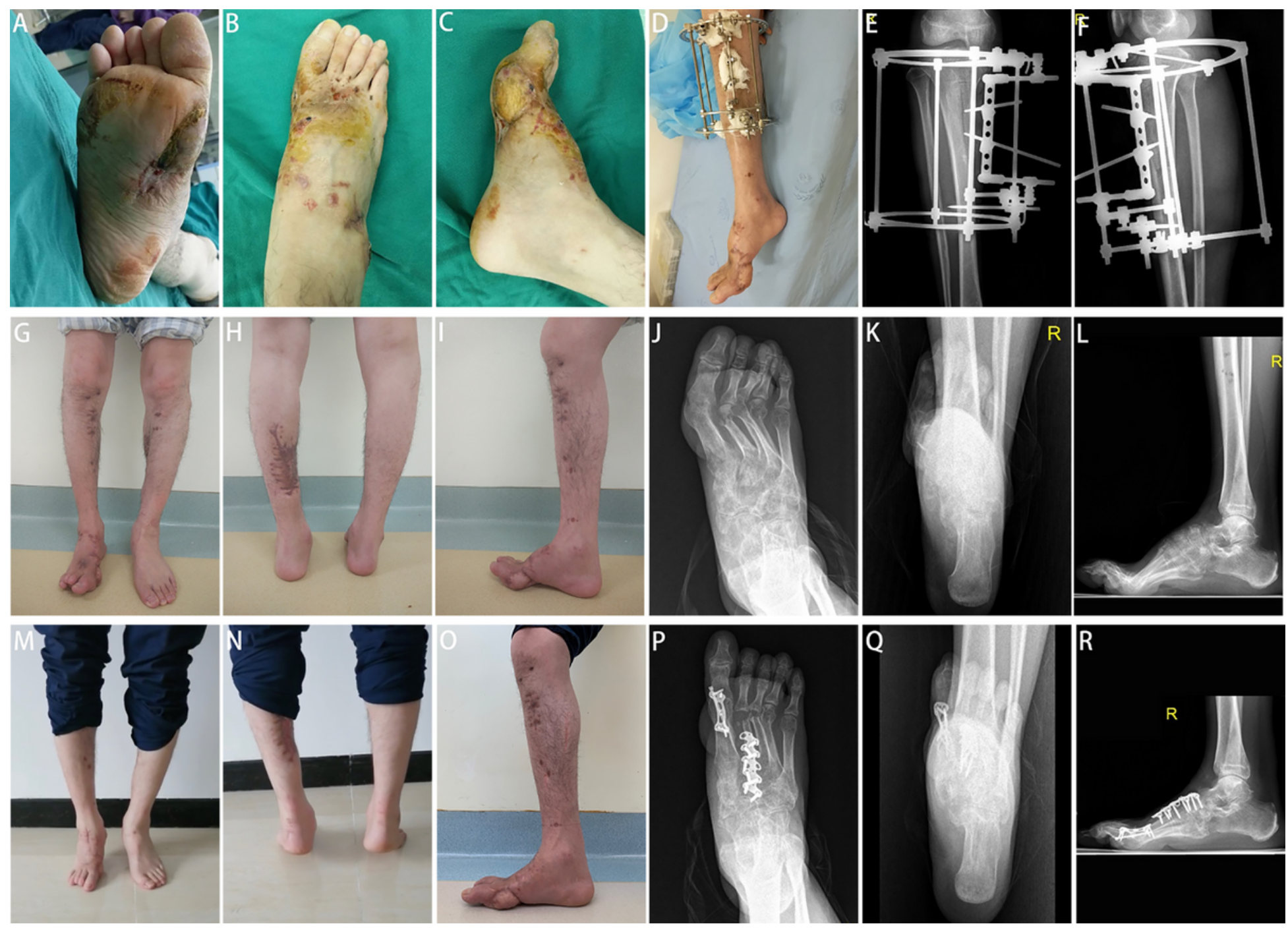

Figure 1

(captions not included) 

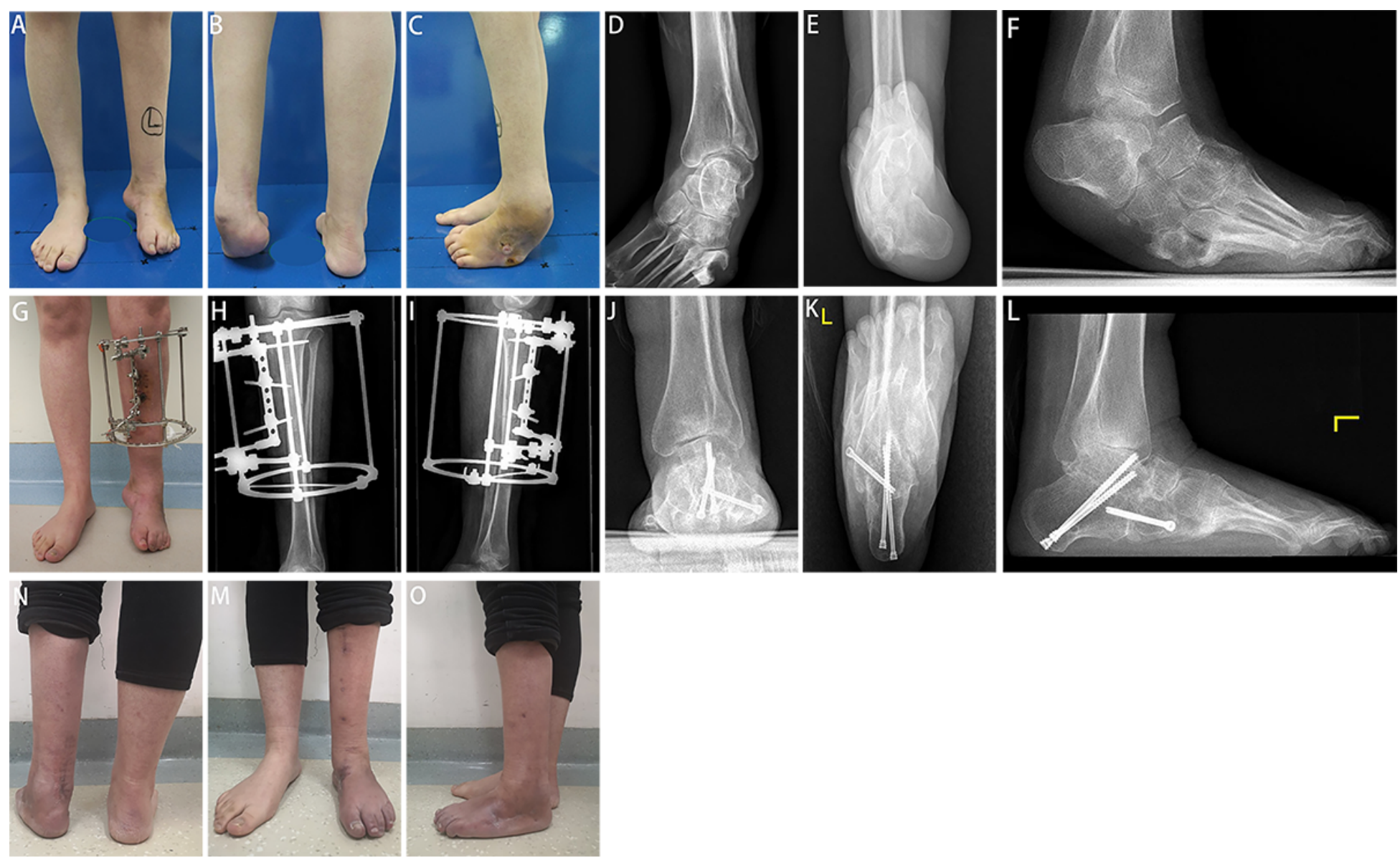

Figure 2

(captions not included) 

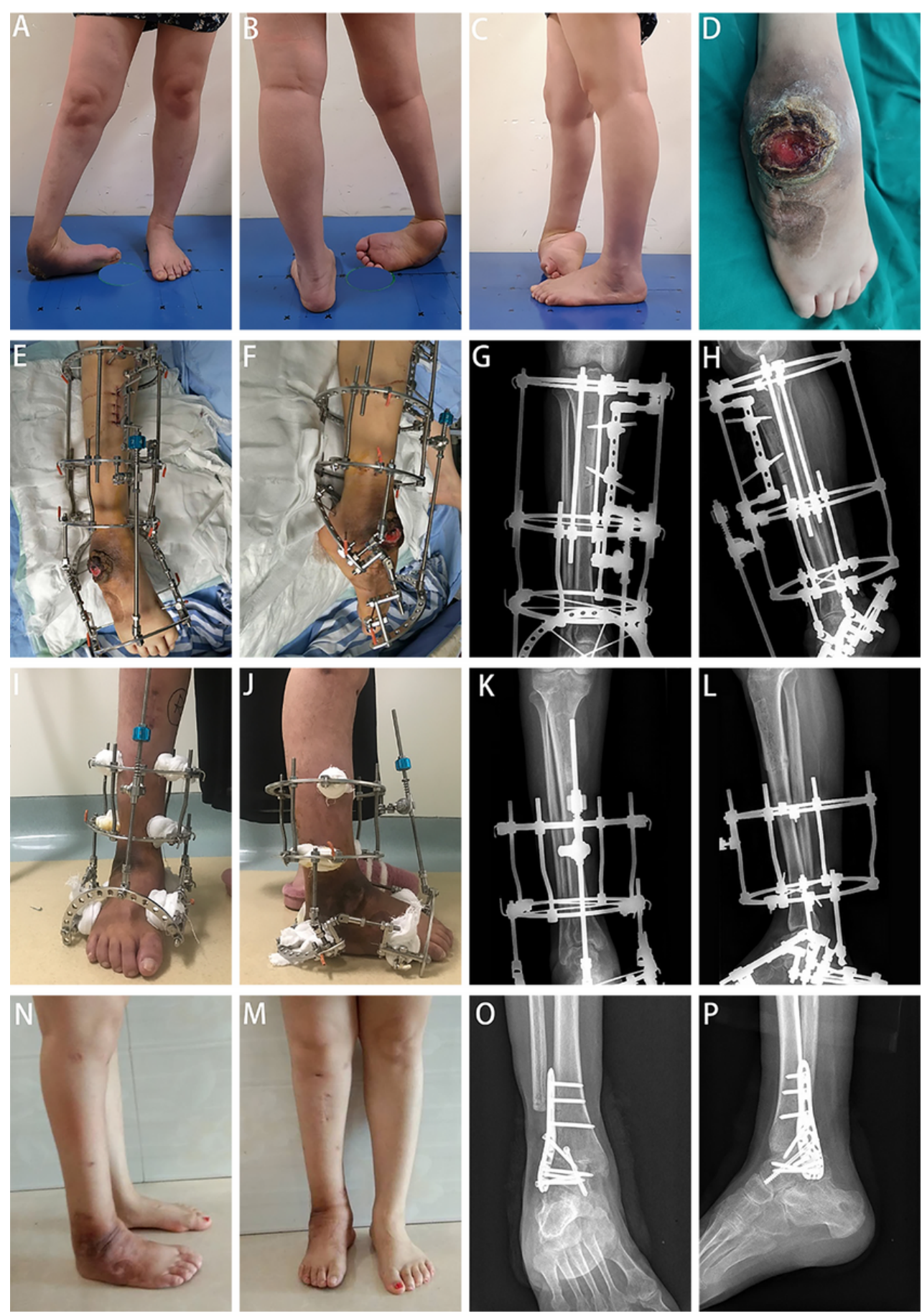

Figure 3

(captions not included) 
A

B
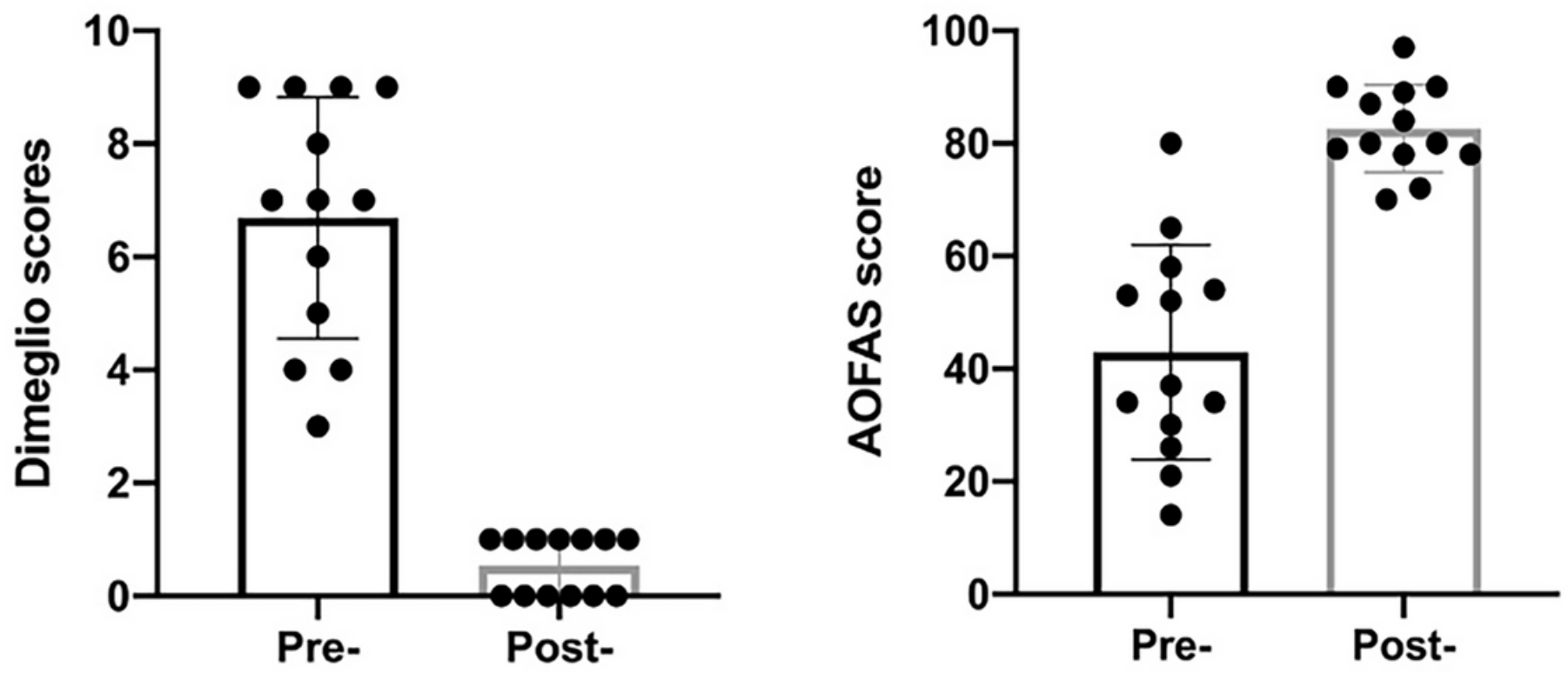

Figure 4

(captions not included) 